\title{
PENGEMBANGAN ALAT PERAGA BAHAYA ROKOK DAN MEKANISME PERNAPASAN PADA PEMBELAJARAN IPA TERPADU DI SMP
}

\author{
Annisa Fikriya ${ }^{1)}$; Dinar Maftukh Fajar"). \\ ${ }^{1)}$ Fakultas Tarbiyah dan Ilmu Keguruan IAIN Jember, Indonesia \\ e-mail: fikriyaannisa@gmail.com.
}

\begin{abstract}
Science learning using conventional methods and the unavailability of learning media can make learning atmosphere less enjoyable. Therefore, we need learning media that can make learning more fun. In addition, we need media that can demonstrate the phenomenon of natural and environmental damage and can socialize the dangers of smoking to students. This is because the danger of smoking is relevant to one of the natural science materials in junior high school, namely the respiratory system. This research aimed to develop props about the dangers of smoking and the respiratory system in learning science in junior high school. This type of research is classified as Research and Development with the ADDIE model developed by Robert Maribe Branch. The data collection instruments used were questionnaires given to media experts to examine the validity of the props and questionnaires given to students to gain their responses about the props. The product developed has been tested by media experts and received a percentage score of $88.4 \%$ which belongs to the "very valid" category. This product has also received positive responses from students and obtained a percentage of student response scores of $81.81 \%$ in the "very interesting" category.
\end{abstract}

Keywords: props, research and development, ADDIE, the dangers of smoking and respiratory system.

\begin{abstract}
Abstrak
Pembelajaran IPA dengan menggunakan metode konvensional ditambah tidak tersedianya media pembelajaran dapat menjadikan suasana belajar menjadi kurang menyenangkan. Oleh karena itu, dibutuhkan sebuah media pembelajaran yang dapat menjadikan suasana belajar lebih menyenangkan. Selain itu, dibutuhkan suatu media yang dapat mendemonstrasikan fenomena kerusakan alam dan lingkungan serta dapat mensosialisasikan bahaya rokok kepada siswa. Hal ini karena bahaya rokok relevan dengan salah satu materi IPA SMP, yaitu sistem pernapasan. Penelitian ini bertujuan untuk mengembangkan alat peraga bahaya rokok dan mekanisme pernapasan pada pembelajaran IPA Terpadu di SMP. Penelitian ini berjenis Penelitian dan Pengembangan (Research and Development) dengan model ADDIE yang dikembangkan oleh Robert Maribe Branch. Instrumen pengumpulan data yang digunakan berupa angket yang diberikan kepada ahli media untuk menguji validitas alat peraga bahaya rokok dan mekanisme pernapasan dan angket yang diberikan kepada siswa untuk mendapatkan respons siswa. Produk yang dikembangkan telah teruji valid oleh para ahli media dan menerima persentase skor $88,4 \%$ yang termasuk kategori "sangat valid". Produk ini juga telah mendapatkan respons positif dari siswa dan memperoleh presentase skor respons siswa $81,81 \%$ dengan kategori "sangat menarik".
\end{abstract}

Kata kunci: alat peraga, Research and Development, ADDIE, bahaya rokok dan mekanisme pernapasan.

\section{PENDAHULUAN}

Pembelajaran merupakan suatu proses yang dapat dijadikan sebagai landasan pembentukan karakter siswa, oleh karena itu orientasi pembelajaran yang sesuai dengan karakter kurikulum seharusnya dapat diterapkan secara maksimal di suatu lembaga pendidikan, misalnya pembelajaran bermakna (meaningful learning) dan pembelajaran tuntas (mastery learning), sehingga siswa dapat memahami materi dengan tingkat pemahaman 
tinggi dan dilaksanakan secara maksimal (Fajar, 2019; Mulyasa, 2013). Sebagian besar siswa mengalami kebosanan dalam kegiatan pembelajaran, karena faktor didaktik, termasuk metode pembelajaran yang berpusat pada guru (Suhardi, 2018).

Ilmu Pengetahuan Alam (IPA) merupakan konsep pembelajaran mengenai gejala alam yang mempunyai hubungan dengan kehidupan manusia dan objek kajian luas, serta ilmu yang lahir dan berkembang lewat langkah-langkah observasi, perumusan masalah, penyusunan hipotesis, pengujian hipotesis melalui eksperimen, penarikan kesimpulan, serta penemuan teori dan konsep (Trianto, 2014). Pembelajaran IPA yang menyajikan konsep nyata dalam kehidupan sehari-hari lebih berpotensi untuk mengembangkan pengalaman dan kompetensi siswa dalam memahami alam dan lingkungan sekitar berdasarkan konsep IPA (Listyawati, 2012).

Beberapa permasalahan pembelajaran IPA berpangkal pada metode dan media yang digunakan guru dalam pembelajaran (Suhardi et al., 2020). Salah satu masalah yang muncul dalam pembelajaran IPA yaitu kesulitan guru dalam menyampaikan konsep IPA melalui fenomena kehidupan sehari-hari. Dengan demikian, perlu adanya perubahan dalam metode pembelajaran yang dapat menarik perhatian siswa agar siswa lebih antusias dalam mengikuti pembelajaran di kelas. Salah satu metode pembelajaran IPA Terpadu yang bisa diterapkan untuk membangun pemahaman konsep dan penerapannya adalah metode praktikum (Abdillah \& Fajar, 2020). Perubahan dalam metode pembelajaran dapat dimulai dengan pemanfaatan media pembelajaran. Sebagaimana paparan diatas, dibutuhkan suatu media yang dapat menarik perhatian siswa pada proses pembelajaran dan mampu menjelaskan kepada siswa tentang materi yang dipelajari.

Salah satu media pembelajaran dengan basis praktikum yang dapat menarik perhatian siswa adalah alat peraga. Dengan metode demonstrasi yang memanfaatkan alat peraga, guru menjadi lebih efisien dalam menjelaskan konsep IPA secara konkret (Sulistyarsi, 2016). Dengan skenario yang telah dirancang dengan baik, alat peraga dapat ditampilkan di depan kelas maupun dioperasikan oleh masing-masing siswa, sehingga hal ini dapat merangsang pikiran, perasaan, minat, serta memori jangka panjang (Anas, 2014). Alat peraga yang digunakan ditekankan menggunakan bahan-bahan yang murah atau daur ulang sehingga memicu kreativitas pembuatnya (Arif Widiyatmoko \& Pamelasari, 2012).

Di samping dapat mendemonstrasikan pengetahuan konseptual sesuai dengan domain kognitif menurut Anderson \& Krathwohl (2001), alat peraga juga dapat mendemonstrasikan pengetahuan faktual berupa kerusakan alam dan lingkungan serta mengajak siswa untuk melakukan hal-hal yang positif dalam konteks IPA (Dewi, 2018; Sari \& Widiyatmoko, 2014). Salah satu materi IPA yang diketengahkan pada tulisan ini adalah materi IPA kelas 8 SMP, yakni Sistem Pernapasan Manusia. Ajakan positif yang dibangun dalam materi ini adalah menjaga kesehatan paru-paru dengan tidak menjadi perokok aktif maupun perokok pasif melalui demonstrasi alat peraga. Hal ini mengingat perilaku merokok di kalangan pelajar menjadi masalah umum di negeri ini. Sosialisasi tentang bahaya rokok merupakan salah satu upaya pencegahan yang dapat dilakukan (Alamsyah \& Nopianto, 2017).

Sejumlah penelitian melaporkan terdapat hubungan yang erat antara pengetahuan dan kebiasaan merokok di kalangan pelajar (Andika et al., 2016; Suhta, 2018; Wirawan, 2017). walaupun pada kasus lain hal ini dipengaruhi oleh faktor-faktor lain yang lebih kompleks (Rahmadi et al., 2013). Pengetahuan yang dimaksud berkaitan dengan wawasan akan kandungan zat-zat berbahaya dalam rokok dan penyakit yang ditimbulkan. Artinya semakin mengetahui bahaya rokok, semakin besar peluang bagi pelajar untuk menghindari kebiasaan merokok. Berkaitan dengan hal tersebut, IPA memiliki posisi yang strategis untuk mensosialisasikan bahaya rokok kepada siswa karena di dalam materi Sistem Pernapasan Manusia dibahas tentang sistem pernapasan, hukum Boyle dalam pernapasan, zat-zat adiktif, dan penyakit-penyakit yang berbahaya akibat terganggunya mekanisme tersebut. 
Alat peraga mekanisme pernapasan telah dikembangkan oleh berbagai peneliti (Dwi Ari, 2018; Uki, 2017). Secara terpisah sosialisasi tentang bahaya rokok juga telah dilakukan oleh peneliti lain yang lebih fokus pada bidang kesehatan (Dharmastuti et al., 2017). Posisi penelitian ini adalah menggabungkan kedua aspek tersebut dalam sebuah alat peraga terpadu, yang mana di samping dapat mendemonstrasikan mekanisme pernapasan, alat peraga ini juga dapat memeragakan kerusakan organ pernapasan akibat kebiasaan merokok sehingga timbul dorongan untuk menghindari kebiasaan merokok. Tulisan ini bertujuan mendeskripsikan validitas alat peraga bahaya rokok dan mekanisme pernapasan pada pembelajaran IPA terpadu di SMP.

\section{METODE}

Penelitian ini menggunakan metode penelitian dan pengembangan (Research and Development). Penelitian pengembangan ini bertujuan untuk menghasilkan sebuah produk yaitu berupa media alat demonstrasi bahaya rokok yang terintegerasi dengan sistem pernapasan manusia dalam pembelajaran IPA terpadu. Model pengembangan dalam penelitian ini menggunakan model yang dikembangkan oleh Robert Maribe Branch, yaitu ADDIE yang memiliki lima alur tahapan yaitu Analyze (Analisis), Design (Desain), Development (Pengembangan), Implementation (Implementasi), dan Evaluation (Evaluasi) (Sugiyono, 2015). Alur pengembangan ditampilkan pada Gambar 1.

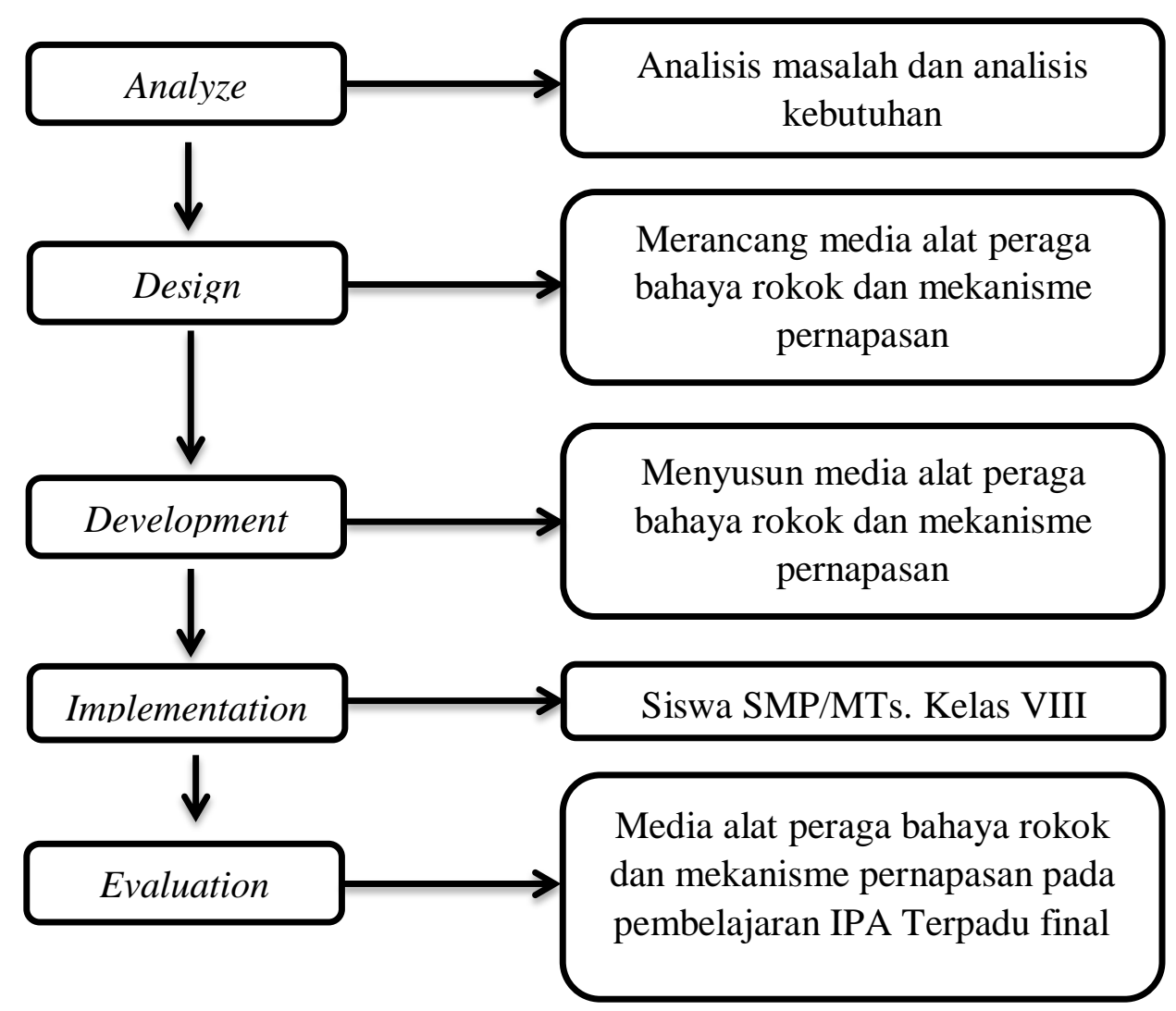

Gambar 1. Diagram alir prosedur penelitian pengembangan alat peraga bahaya rokok dan mekanisme pernapasan pada pembelajaran IPA Terpadu dengan model pengembangan ADDIE

Data penelitian yang didapatkan berupa hasil penilaian validasi dan hasil respons siswa, keduanya diperoleh secara kuantitatif (angka-angka) maupun kualitatif (komentar, saran, dan kritik terhadap produk). Penilaian validasi alat peraga bahaya rokok dan 
mekanisme pernapasan diberikan oleh 5 orang ahli media, yang terdiri dari 3 dosen pendidikan IPA, 1 dosen kesehatan masyarakat, dan 1 orang guru mata pelajaran IPA. Sementara respons siswa diberikan oleh siswa MTs Al Misri Jember, Jawa Timur sebanyak 59 orang, yaitu 24 siswa dari kelas VIII A dan 35 siswa dari kelas VIII B.

Aspek penilaian validasi dimodifikasi dari Sugiyono (2015) yang meliputi pertimbangan (1) kefungsian, yakni sejauh mana produk dapat memenuhi fungsi atau tujuan pembuatannya; (2) tampilan, yakni sejauh mana produk dapat memberikan kesan menarik bagi penggunanya; (3) kepraktisan, yakni sejauh mana produk dapat dioperasikan dengan mudah; dan (4) kehandalan, yakni seberapa awet atau sejauh mana produk dapat digunakan berulang-ulang dalam waktu yang lama. Sementara aspek respons siswa dimodifikasi dari Jalil (2016) dan A. Widiyatmoko (2013) antara lain tampilan, kemudahan penggunaan, kemudahan pemahaman, kemanfaatan, dan kefungsian.

Data penelitian diperoleh dengan menggunakan lembar angket validasi ahli media dan lembar angket respons siswa. Penilaian diberikan dengan menggunakan skala likert 1-5. Kriteria dalam skala penilaian menggunakan skala likert ditampilkan pada Tabel 1.

\section{Tabel 1. Kriteria Skala Penilaian}

\begin{tabular}{lc}
\hline \multicolumn{1}{c}{ Kriteria } & Skor \\
\hline Sangat Baik (SB) & 5 \\
Baik (B) & 4 \\
Cukup (C) & 3 \\
Kurang (K) & 2 \\
Sangat Kurang (SK) & 1 \\
\hline
\end{tabular}

Hasil validasi diperoleh dengan cara menghitung rata-rata jawaban dari setiap validator. Teknik perhitungan presentase yang diadaptasi oleh Akbar (2013) dengan rumus sebagai berikut.

$$
\begin{aligned}
& \quad-\times 100 \% \\
& \text { Keterangan: } \\
& \text { : Validasi } \\
& \text { : Jumlah skor yang diberikan validator untuk masing-masing aspek } \\
& \text { : Skor maksimum untuk setiap kriteria }
\end{aligned}
$$

Kriteria validitas alat peraga ditampilkan pada Tabel 2.

Tabel 2. Kriteria Uji Validitas Alat Peraga

\begin{tabular}{cl}
\hline Kriteria & \multicolumn{1}{c}{ Tingkat Validitas } \\
Validitas & \\
\hline $81 \%-100 \%$ & Sangat valid atau dapat digunakan tanpa revisi \\
$61 \%-80 \%$ & Valid atau dapat digunakan namun perlu revisi sedikit \\
$41 \%-60 \%$ & Kurang valid, disarankan tidak dipergunakan karena perlu revisi besar \\
$21 \%-40 \%$ & Tidak valid atau tidak boleh dipergunakan \\
$0 \%-20 \%$ & Sangat tidak valid atau tidak boleh dipergunakan \\
\hline
\end{tabular}

Presentase hasil respons siswa yang memberikan tanggapan sesuai dengan kriteria tertentu, seperti yang dituliskan rumus sebagai berikut.

$$
V-a u=-100 \%
$$


Keterangan:

$V$ - au : Validasi audien (nilai persentase)

Tse : Total skor empirik yang didapatkan dari respons siswa

Tsh : Total skor yang diharapkan

Kriteria kemenarikan produk berdasarkan respons siswa terhadap media pembelajaran dapat dilihat pada Tabel 3 .

Tabel 3. Kriteria Hasil Respons Siswa

\begin{tabular}{ll}
\hline Penilaian & Kriteria \\
\hline $81 \%-100 \%$ & Sangat Menarik \\
$61 \%-80 \%$ & Menarik \\
$41 \%-60 \%$ & Cukup Menarik \\
$21 \%-40 \%$ & Tidak Menarik \\
$0 \%-20 \%$ & Sangat Tidak Menarik \\
\hline & Sumber: (Akbar, 2013).
\end{tabular}

\section{HASIL DAN PEMBAHASAN}

Penelitian ini merupakan pengembangan alat peraga bahaya rokok dan mekanisme pernapasan pada pembelajaran IPA Terpadu di SMP dengan menggunakan model ADDIE (Analyze, Design, Development, Implementation \& Evaluation). Hasil dari penelitian pengembangan alat peraga ini ialah sebagai berikut.

\section{Analisis (Analyze)}

Tahap ini dilakukan guna mengetahui keadaan, permasalahan dan kebutuhan yang terjadi dalam pembelajaran yaitu terdiri dari dua analisis yaitu analisis masalah (problem analyze) dan analisis kebutuhan (need analyze).

a. Hasil Analisis Masalah

Analisis masalah merupakan langkah awal observasi yang dilakukan oleh peneliti untuk mengetahui permasalahan yang ada di sekolah dan berkaitan dengan materi pelajaran. Peneliti melakukan observasi langsung ke sekolah, yakni MTs. Al-Misri Curahmalang, Rambipuji, Jember dan mengetahui adanya permasalahan berupa peraturan larangan merokok yang dilanggar oleh siswa. Hal ini bersesuaian dengan konteks pembelajaran yang sedang berlangsung, yakni materi IPA Sistem Pernapasan Manusia. Peneliti juga mendapat informasi terkait metode pembelajaran yang diterapkan yakni menggunakan metode ceramah. Guru kelas juga melaporkan bahwa suasana belajar belum maksimal sehingga guru membutuhkan sarana baru agar kualitas pembelajaran dapat ditingkatkan.

b. Analisis Kebutuhan

Analisis kebutuhan dilakukan untuk menentukan media pembelajaran yang dibutuhkan oleh siswa dalam meningkatkan kualitas belajar siswa. Dengan diketahuinya keadaan dan permasalahan yang ada, maka peneliti merancang sebuah alat peraga yang dapat digunakan sebagai media pembelajaran sekaligus untuk mensosialisasikan bahaya rokok kepada siswa.

\section{Perancangan (Design)}

Pada tahap ini adalah tahap merancang alat peraga. Alat peraga dirancang sesuai dengan materi sistem pernapasan yang dikombinasikan dengan bahaya rokok.

Alat peraga yang dikembangkan tergolong alat peraga murah yakni dibuat dengan memanfaatkan barang-barang sederhana atau daur ulang. Pertimbangan ini dipilih karena beberapa alasan yaitu ketersediaan, faktor biaya, dan faktor lingkungan. Manfaat yang dapat diambil dari pembuatan alat peraga murah adalah membangun efisiensi dan kreativitas serta 
mempromosikan sikap peduli lingkungan baik pada pembuatnya maupun kepada siswa (A. Widiyatmoko, 2013). Bahan-bahan yang digunakan antara lain triplek $65 \times 45 \mathrm{~cm}$, botol plastik, kapas, balon 4 buah, sedotan, selang, suntikan, poster paru-paru manusia, dan beberapa sampel rokok yang berfilter dan tidak berfilter. Gambar 2 dan 3 adalah tampilan alat peraga yang dikembangkan.

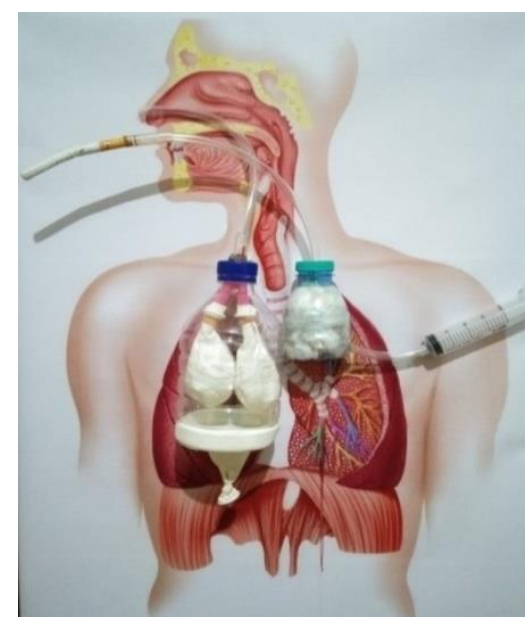

(a)

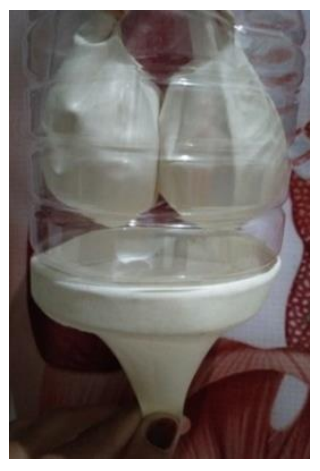

(b)

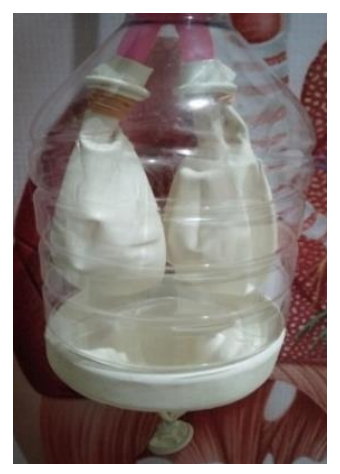

(c)

Gambar 2. Alat Peraga: (a) tampilan depan, dua balon (paru-paru) (b) mengembang dan (c) mengempis untuk mendemonstrasikan Hukum Boyle



(a)

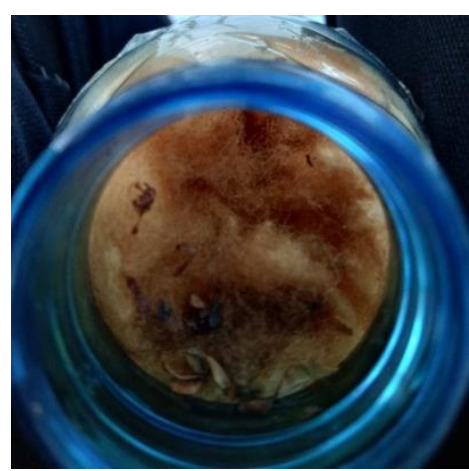

(b)

Gambar 3. (a) Asap rokok masuk melalui selang yang berfungsi sebagai mulut dan tenggorokan (b) Warna hitam kapas setelah merokok sebanyak 4 bungkus rokok

Gambar 3 (b) diperoleh setelah melakukan pengujian percobaan merokok sebanyak 4 bungkus dengan jumlah 48 batang rokok yang tidak berfilter. Pengujian ini dilakukan sebelum ditampilkan di kelas. Untuk menghabiskan sebatang rokok dapat dilakukan penghisapan sebanyak 362 kali tarikan. Semakin banyak batang rokok yang dihisap maka semakin hitam warna kapas yang dihasilkan. Hal ini karena di dalam batang rokok terdapat zat tar yang dapat mengakibatkan kapas berwarna hitam (Heriaw, 2017). Warna hitam pada kapas ini (botol alveolus) merupakan demonstrasi kerusakan organ paru-paru perokok aktif akibat penumpukan tar (Triana et al., 2013).

Alat peraga yang dikembangkan juga dilengkapi dengan buku petunjuk penggunaan. Di dalam buku petunjuk penggunaan dipaparkan tentang keterpaduan IPA (fisika, kimia, dan biologi) dalam alat peraga untuk memudahkan guru dalam menerangkan, skenario 
pembelajaran dengan metode demonstrasi, dan gambar-gambar hasil akhir pengujian percobaan merokok yang dilakukan oleh peneliti.

\section{Pengembangan (Development)}

Pada tahap ini adalah proses pengembangan alat peraga yang sudah dirancang pada tahap perancangan (desain) dan menghasilkan sebuah produk alat peraga. Berikut adalah hasil validasi oleh ahli media.

a. Hasil Validasi Ahli Media

Validasi ahli media ini bertujuan untuk mengetahui kelayakan atau validitas media alat peraga yang telah dibuat. Hal ini dilakukan dengan mengisi lembar instrumen penilaian yang terdiri 4 aspek diantaranya aspek kefungsian alat peraga, tampilan alat peraga, kepraktisan alat peraga, dan kehandalan alat peraga. Hasilnya dapat dilihat pada Gambar 4.

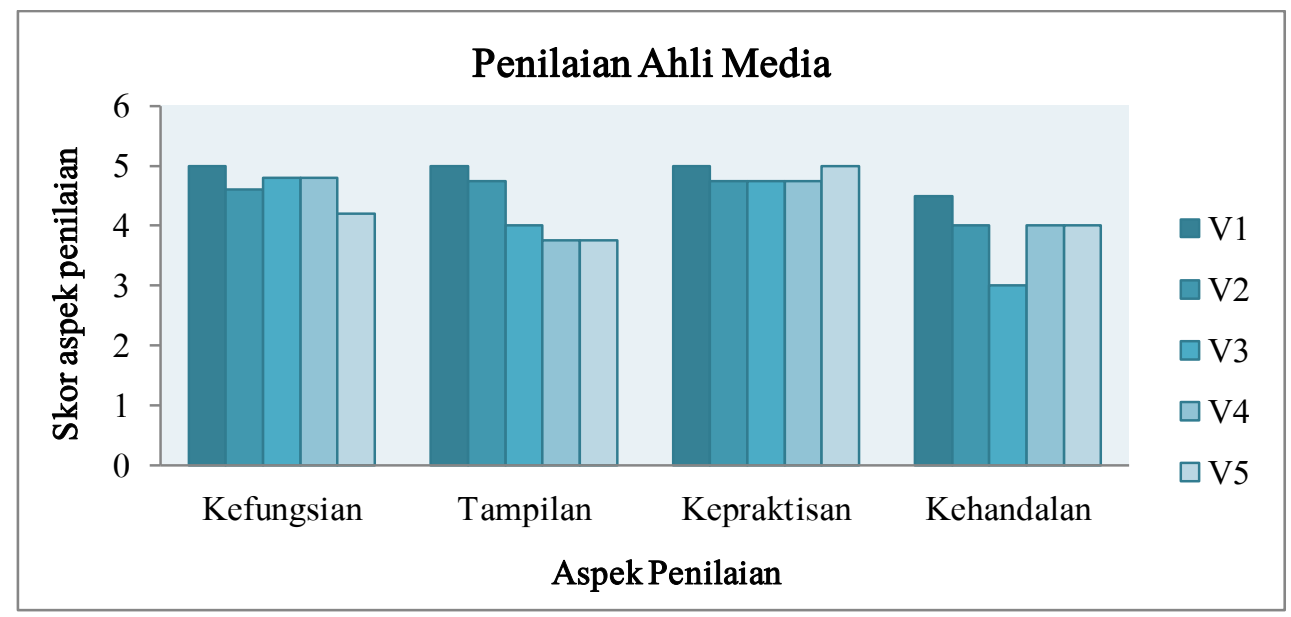

\section{Gambar 4. Diagram batang penilaian ahli media}

Berdasarkan hasil validasi ahli media alat peraga bahaya rokok dan mekanisme pernapasan dapat diketahui bahwa total presentase hasil penilaian aspek oleh validator adalah 88,4 \% dengan kategori "Sangat Valid".

b. Hasil Respons Siswa

Hasil uji respons dilakukan oleh 59 siswa, yaitu 24 siswa dari kelas VIII A dan 35 siswa dari kelas VIII B. Hasil respons siswa yang diperoleh dapat dilihat pada Gambar 5.

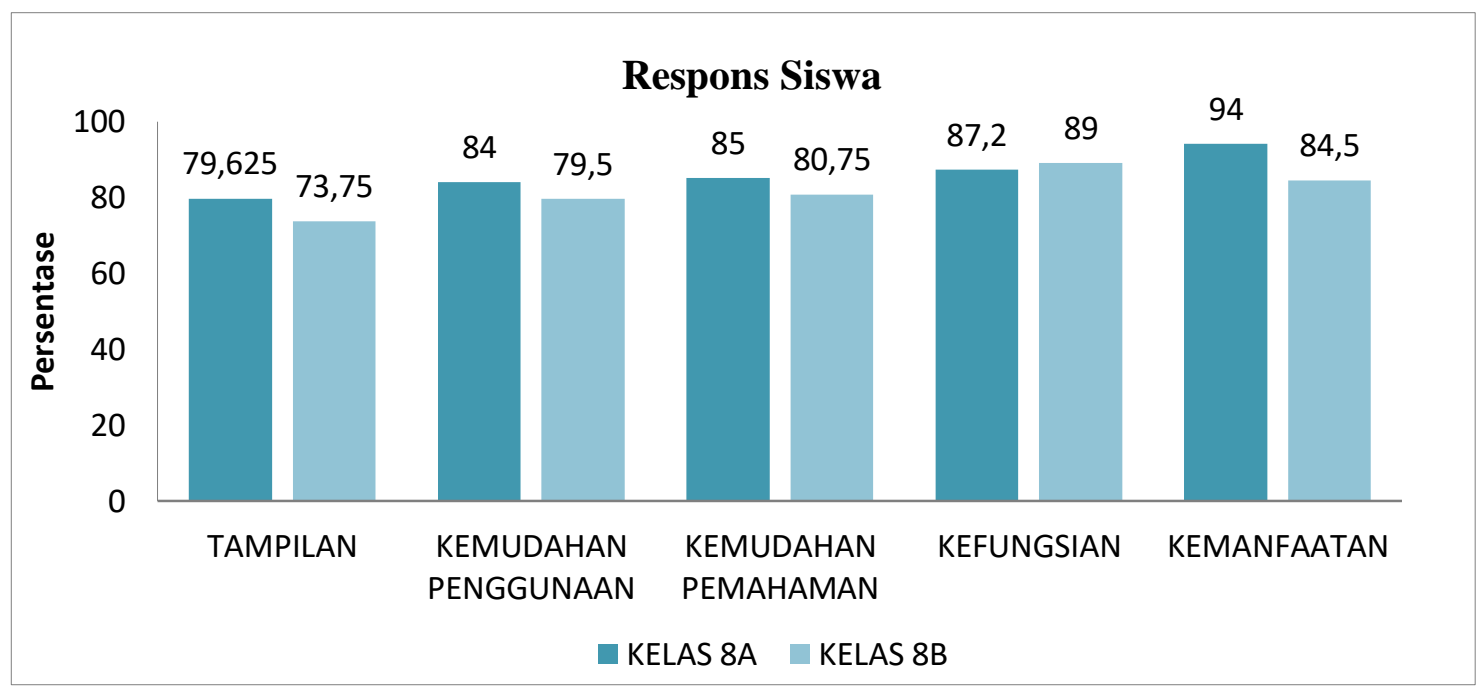

Gambar 5. Hasil respons siswa 
Berdasarkan hasil respons siswa terhadap alat peraga bahaya rokok dan mekanisme pernapasan pada pembelajaran IPA Terpadu dapat diketahui secara keseluruhan total presentase rata-rata hasil penilaian aspek sebesar 81\% dengan kategori "Sangat Menarik".

\section{Implementasi (Implementation)}

Tahap implementasi dilakukan pada saat kegiatan belajar mengajar. Peneliti menggunakan media pembelajaran berupa alat peraga bahaya rokok dan mekanisme pernapasan pada materi sistem pernapasan manusia di kelas VIII A dan VIII B MTs. Al-Misri Curahmalang, Rambipuji, Jember. Setelah siswa belajar menggunakan alat peraga, siswa diminta mengisi angket respons yang telah dibagikan peneliti terkait alat peraga yang telah dikembangkan dan digunakan sebagai media pembelajaran. Proses pembelajaran dilakukan sebanyak 3 pertemuan secara klasikal pada bulan Februari 2020 sebelum masa belajar di rumah akibat pandemi Covid-19. Dari observasi tampak bahwa aktivitas siswa di dalam kelas meningkat, siswa menjadi lebih antusias dan penasaran terhadap demonstrasi produk. Hal ini sesuai dengan Umayah et al. (2013) bahwa pemanfaatan alat peraga 3 dimensi dapat meningkatkan aktivitas siswa.

\section{Evaluasi (Evaluation)}

Tahap ini dilakukan untuk mengevaluasi hasil pengembangan produk secara keseluruhan. Pada tahap ini peneliti juga dapat memperoleh deskripsi kelebihan dan kekurangan produk.

Secara umum respons siswa terhadap alat peraga adalah positif. Sekitar $80 \%$ siswa mengatakan bahwa alat peraga ini mudah digunakan. Sekitar $75 \%$ siswa setuju bahwa alat peraga ini memiliki tampilan yang menarik. Nilai ini dapat dimaklumi sesuai dengan beberapa komentar validator bahwa komponen-komponen alat peraga masih perlu diperkuat dengan rapi. Sekitar $80 \%$ siswa mengatakan bahwa dengan alat peraga ini materi sistem pernapasan manusia dan Hukum Boyle menjadi mudah dipahami. Alat peraga ini telah dapat menunjukkan bahwa merokok berbahaya bagi paru-paru. Sebagian besar siswa juga mengaku tidak akan mencoba merokok setelah melihat demonstrasi alat peraga ini. Hal ini menjadi konfirmasi temuan bahwa pencegahan kebiasaan merokok dapat dibangun dari peningkatan pengetahuan akan bahaya rokok (Andika et al., 2016; Sari \& Widiyatmoko, 2014; Suhta, 2018; Wirawan, 2017).

Salah satu komentar validator mengenai penyempurnaan alat peraga ini ke depannya adalah hendaknya balon langsung terpisah sebagai paru-paru kanan dan kiri, tidak dijadikan satu dalam satu botol. Yang kedua, salah satu atau kedua balon diisi kapas sebagai alveolusnya agar tidak terjadi miskonsepsi adanya pemisahan antara paru-paru dengan alveolus.

Berdasarkan pendapat tersebut, peneliti menyimpulkan bahwa dalam proses pembelajaran, guru tetap harus memberikan penjelasan tambahan bahwa botol alveolus yang dipasang terpisah dengan botol paru-paru pada hakikatnya adalah satu organ paru-paru. Pada alat peraga dibuat terpisah karena beberapa alasan. Pertama, karena lubang mulut / hidung merupakan satu-satunya jalur keluar masuk udara sehingga tidak dapat sekaligus mendemonstrasikan mekanisme menghembuskan napas (exhale) dan menarik napas (inhale) sementara rokok masih terpasang pada lubang mulut. Kedua, karena tidak adanya balon berwarna bening yang dapat menampilkan kerusakan paru-paru atau alveolus akibat rokok. Ketiga, hal ini juga dapat memberikan keuntungan dalam proses penyampaian kepada siswa, yakni demonstrasi alat peraga tentang mekanisme pernapasan, hukum Boyle, dan bahaya rokok dapat dilakukan secara berurutan dan sistematis. 


\section{SIMPULAN}

Berdasarkan penilaian ahli media pada seluruh aspek, validitas alat peraga bahaya rokok dan mekanisme pernapasan dalam pembelajaran IPA Terpadu di SMP mendapatkan total nilai presentase sebesar $88,4 \%$ sehingga termasuk kategori "sangat valid". Respons siswa terhadap alat peraga mendapat presentase sebesar $81,81 \%$ dengan kategori "sangat menarik". Berdasarkan data tersebut dapat disimpulkan bahwa alat peraga yang dikembangkan sangat menarik, mudah dipahami, dan mendorong rasa ingin tahu siswa terhadap bahaya rokok.

\section{UCAPAN TERIMA KASIH}

Penulis menyampaikan terima kasih kepada MTs. Al-Misri Curahmalang, Rambipuji, Jember atas bantuan dan kerjasamanya dalam pengambilan data penelitian.

\section{DAFTAR PUSTAKA}

Abdillah, A., \& Fajar, D. M. (2020). Peningkatan Motivasi Belajar Siswa di Kelas VIII SMP Negeri 1 Ajung Melalui Praktikum GLB dan GLBB. EKSAKTA: Jurnal Penelitian Dan Pembelajaran MIPA, 5(1), 48-54.

Akbar, S. (2013). Instrumen perangkat pembelajaran. Bandung: PT Remaja Rosdakarya.

Alamsyah, A., \& Nopianto, N. (2017). Determinan Perilaku Merokok Pada Remaja. Jurnal Endurance, 2(1), 25-30.

Anas, M. (2014). Alat peraga dan media pembelajaran. Pustaka Education.

Anderson, L. W., \& Krathwohl, D. R. (2001). A revision of Bloom's taxonomy of educational objectives. A Taxonomy for Learning, Teaching and Assessing. Longman, New York.

Andika, D., Khairsyaf, O., \& Pertiwi, D. (2016). Hubungan pengetahuan dengan kejadian merokok pada pelajar SMPN 1 Pariaman. Jurnal Kesehatan Andalas, 5(2).

Dewi, R. (2018). Meningkatkan Kemampuan Belajar Siswa Melalui Pemanfaatan Alat Peraga Materi Kondisi Lingkungan Geografis Tema Selamatkan Makhluk Hidup Pelajaran IPS. E-Jurnal Mitra Pendidikan, 2(11), 1249-1258.

Dharmastuti, S. P., Kusumawati, Y., \& Wijayanti, A. C. (2017). Pengaruh Pendidikan Kesehatan Tentang Bahaya Merokok Melalui Media Booklet Dan Poster Terhadap Pengetahuan Dan Sikap Siswa Smp N 2 Tasikmadu [PhD Thesis]. Universitas Muhammadiyah Surakarta.

Dwi Ari, L. (2018). Peningkatan pemahaman siswa kelas V pada materi sistem pernapasan manusia dengan menggunakan alat peraga mekanisme pernapasan manusia di SD ma'arif YPM Wonocolo Sidoarjo [PhD Thesis]. UIN Sunan Ampel Surabaya.

Fajar, D. M. (2019). Menggapai Hikmah dalam Pembelajaran Sains. CV Lintas Nalar.

Heriaw, N. Q. (2017). Distribusi Frekuensi Perubahan Warna Email Gigi Pada Perokok. Cakradonya Dental Journal, 9(2), 116-120.

Jalil, R. M. (2016). Kelayakan Media Alat Peraga Air Mancur Sederhana Untuk Meningkatkan Pemahaman Konsep Pada Materi Hukum Boyle. Pensa: Jurnal Pendidikan Sains, 4(03).

Listyawati, M. (2012). Pengembangan perangkat pembelajaran IPA Terpadu di SMP. Journal of Innovative Science Education, 1(1).

Mulyasa, E. (2013). Pengembangan dan implementasi kurikulum 2013. PT Remaja Rosdakarya.

Rahmadi, A., Lestari, Y., \& Yenita, Y. (2013). Hubungan pengetahuan dan sikap terhadap rokok dengan kebiasaan merokok siswa smp di kota padang. Jurnal Kesehatan Andalas, 2(1), 25-28. 
Sari, A. M., \& Widiyatmoko, A. (2014). Pengembangan Alat Peraga Pemanasan Global Berbahan Bekas Pakai Untuk Menanamkan Karakter Peduli Lingkungan. Unnes Science Education Journal, 3(3).

Sugiyono, M. (2015). Penelitian \& pengembangan (Research and Development/R\&D). Bandung: Penerbit Alfabeta.

Suhardi, A. (2018). Pengaruh Penggunaan Mind Map Terhadap Pemahaman Konsep Pendidikan Agama Islam Bagi Mahasiswa Iain Jember. Indonesian Journal of Islamic Teaching, 1(1), 29-29.

Suhardi, A., Susanti, L. Y., \& Susilawati, S. (2020). Pengaruh Penggunaan Mind Map Terhadap Pemahaman Konsep Stoikiometri. Journal of Natural Science and Integration, 3(1), 106-114.

Suhta, D. W. (2018). Pengetahuan dan Perilaku Merokok Pelajar Sekolah Menengah Pertama. Jurnal Manajemen Kesehatan Yayasan RS. Dr. Soetomo, 4(1), 47-60.

Sulistyarsi, A. (2016). Penerapan Strategi Pembelajaran Berbasis Proyek dalam Membuat Alat Peraga IPA untuk Meningkatkan Prestasi Belajar dan Keaktifan Siswa Kelas IV SDN Cermo 01 Kare Madiun. Premiere Educandum: Jurnal Pendidikan Dasar Dan Pembelajaran, 2(01).

Triana, N., Ilyas, S., \& Hutahaean, S. (2013). Gambaran Histologis Pulmo Mencit Jantan (Mus musculus L.) Setelah Dipapari Asap Rokok Elektrik. Saintia Biologi, 1(2), 1-7.

Trianto, T. (2014). Model Pembelajaran Terpadu; Konsep, Strategi dan Implementationnya dalam KTSP. Jakarta: Bumi Aksara.

Uki, N. M. (2017). Penerapan Model Pembelajaran Kooperatif Tipe NHT Berbantuan Alat Peraga Sistem Pernapasan Manusia. Proceeding Biology Education Conference: Biology, Science, Enviromental, and Learning, 14(1), 329.

Umayah, S., Haryani, S., \& Sumarni, W. (2013). Pengembangan kartu bergambar tiga dimensi sebagai media diskusi kelompok pada pembelajaran ipa terpadu tema kehidupan. Unnes Science Education Journal, 2(2).

Widiyatmoko, A. (2013). Pengembangan perangkat pembelajaran ipa terpadu berkarakter menggunakan pendekatan humanistik berbantu alat peraga murah. Jurnal Pendidikan IPA Indonesia, 2(1).

Widiyatmoko, Arif, \& Pamelasari, S. D. (2012). Pembelajaran berbasis proyek untuk mengembangkan alat peraga IPA dengan memanfaatkan bahan bekas pakai. Jurnal Pendidikan IPA Indonesia, 1(1).

Wirawan, A. S. (2017). Hubungan Antara Pengetahuan Dan Sikap Tentang Bahaya Merokok Bagi Kesehatan Dengan Tindakan Merokok Pelajar SMK Negeri Talaga. 